\title{
VELED A TÖPRENGÉS NAGYON ÉRDEKES LETT, KÍVÁNCSIVÁ TETTÉL
}

\section{CZIKE BERNADETT}

a Pannon Egyetem Modern Filológiai és Társadalomtudományi Karának egyetemi docense czdetti@yahoo.com

\section{Kedves Juli!}

Olyan hangulatban kellene lenni, hogy meg tudjam ezt írni most, de szerencsére, ahogy rád gondolok, olyan hangulatban leszek. Nagyon fontos dolgok történtek velem, amikor veled voltam, egy-egy szó, egy-egy gondolat, sok éven át megmaradt. Keveset, de fontosakat beszélgettünk.

\section{Először}

Az első emlékem, az első matematika óra, amit tartottál nekünk a Bezerédi utcában. A Tanítóképzö ${ }^{1}$ speciális tagozatára jártam. Én 20 éves lehettem, Te 31. Mindketten nagyon fiatalok voltunk. Azt kérdezted, mit gondoltok, mennyi a valószínüsége annak, hogy a lottón 5 találatosunk lesz? Elöször fordult elö életemben matematika órán, hogy olyasmit kérdezett egy tanár, ami engem érdekelt... Próbálgattuk, gondolkodtunk, hosszú-hosszú ideig kerestük a megoldást, amit végül úgy hívtak: 90 faktoriálisból 5 faktoriális. Erre azonban csak pár óra elteltével derült fény, addig együtt gondolkodtunk. Legalábbis nekem úgy tünt. Azt is mondtad nekünk, hogy az 1, 2, 3, 4, 5-nek a lottón ugyanakkora az esélye, mint minden más variációnak. Nem hittük el, de azután közösen bebizonyítottuk. Egy életre megjegyeztem, mert ez jól mutatja, mekkora képtelenség, hogy nyerjünk.

Azután meghívtál minket, a csoportodat, az otthonodba, mivel Te voltál a csoportvezető tanárunk. Elmentünk hozzád, lakótelepi lakás volt, épp nem olyan régen váltál el a férjedtöl, még Radnainé Szendrei Juliannaként ismertelek meg. A lakás egy „nagyszobából” és két igazán kicsi szobából állt. Először láttam olyat, amit ott nálad: nevezetesen a nagyszoba a két kicsi gyereké volt, Marci és Karcsi, 4 és 2 évesek lehettek, és ott volt a holmijuk, az ágyuk - Hadd mozogjanak! - mondtad, Te pedig a négy négyzetméteres hálóban voltál a holmijaiddal, minden szükséges dologgal felszerelkezve. Volt még egy étkező, ahol éppen elfért egy akkoriban divatos sarok étkezőgarnitúra mübőrből, ezen ültünk, 10-15 tanítványod és Te. Ahogyan ott nálad láttam, attól hirtelen teljesen természetes és magától értetődő lett az, amit addig sehol sem láttam, és amire addig soha nem gondoltam, mármint, hogy

${ }^{1}$ Budapesti Tanítóképző Főiskola 
a nagyszoba nem a felnőttek által bitorolt nappali, és a gyerekszoba nem a négy négyzetméteres kisszoba, hanem fordítva.

Így voltam nagyon sok gondolatoddal: elöször tőled hallottam, tőled láttam, Te mutattad nekem, de attól a perctöl beépült, teljesen magától értetődő, teljesen egyértelmü lett számomra. Világos volt: így kell lennie! Ja igen, így tényleg jobb, sőt, így jó.

A következő közös képünkön, a Böszörményi úton sétálunk, a közért előtt megyünk el. Én 32 éves lehetek, Te 43. Panaszkodtam neked, nem értem, miért hízom, hiszen alig eszem. Erre azt mondtad: Lehet, hogy nem az a baj, amit eszel, hanem amit nem eszel. Csodálkoztam: mi a csudát beszél már megint ez a nő? - Ha nem eszel olyasmiket, amik segítenek feldolgozni az ételt: zöldség, gyümölcs, rostos izék - akkor persze, hogy hízol. Egyél többet, mindig egyél ahhoz, amit eszel, ilyesmiket is! - mondtad. Megint elöször hallottam ilyet valakitől és megint úgy tünt, ez teljesen logikus és magától értetődő.

Sokszor fordult elő a következő: csak ülünk, beszélgetünk, mindenféléket mondasz, teljesen kusza már a kép, semminek semmi köze egymáshoz. Összezavarsz. Mi köze ennek a sok mindennek ahhoz, amit kérdeztem, sőt: mi köze egymáshoz? És amikor már elveszteném a türelmemet, éppen azt mondanám, na jó, Juli, most már beszéljünk másról, akkor mondasz egy szót vagy egy mondatot, ami összerakja egy pillanat alatt az előző gondolatokat. Ami egybefüzi azt, ami eddig teljesen parttalannak, összefüggéstelennek látszott.

\section{A különleges}

Mindenkinek az a célja: nyomot hagyni. Különlegesnek lenni. Mindenki akar ilyen lenni. Neked nem kellett akarni. A magad módján, csendben, mosolyogva, nyugodt hangon mondtál és tettél olyasmiket, amik teljesen egyedivé és különlegessé tettek téged. Nagy öröm volt veled lenni, a barátodnak lenni.

Hallgatni a csendet veled, a mondatok és a szavak között. Átlényegülni egy olyan világba, ahol minden másképpen van, ahol minden lehetséges. Ahol fontosak vagyunk, ahol a gondolatok és az érzelmek uralkodnak. Mindig szerettél töprengeni és veled a töprengés nagyon érdekes lett, kiváncsivá tettél mindenkit, aki erre fogékony volt körülötted.

Elhitetted, hogy az élet csupa titok, hogy mindenen érdemes filózni, hogy lassan-lassan mindenre rá lehet majd jönni, egyszer. Szerettél élni. Talán ez volt az, ami miatt nem akartad, nem tudtad elhinni a halált és valószínűleg nem is haltál meg, máshol vagy, kíváncsian nézel a világba, meghallgatod azokat, akik körülötted vannak, és a legjobb tanácsot adod nekik, olyat, amit jó, ha megfontolnak.

Sok jóképü férfival láttalak, híres és kevésbé híres emberek örülhettek, hogy egy ilyen nő szóba állt velük. Sokszor láttalak boldognak, szerelmesnek, igazi nő is voltál a tudós mellett, a matematika professzora szerette az életet, a jó dolgokat benne. Persze a férfiakról meg is volt a véleményed, lehetett veled pletykálni, de 
nem sok szót pazaroltál. Fantasztikus érzéked volt ahhoz, hogyan lehet a legrosszabbat is jóra fordítani, hogyan lehet a kemóból jópofát faragni, miként tudsz tanulni a betegségedből, miként tudod átadni másoknak, mit csináljanak, ha ilyesmi történik velük.

Ügyesen forgattad a szavakat, jól vagyok, mondtad, most egy kicsit bemegyek a kórházba, de mindjárt jövök és folytathatjuk.

Juli, mikor jössz?

Mindenesetre minden héten megteszem a lottón az 1, 2, 3, 4, 5-öt.

Egyszer biztos bejön. 